\title{
A Study of Competitive Sport Anxiety in Young Soccer Players
}

\author{
Mohammad Ahsan, ${ }^{*}$ Katarina Toga Ruru*, Anand Kumar** \\ (*School of Education, College of Humanities and Education, Fiji National University; FIJI) \\ (**Department of Education, Shri Guru Ram Rai (PG) College, Dehradun, India)
}

\begin{abstract}
Competitive sport anxiety, is common in young soccer players, It is the state of uneasiness and apprehension, about competitive sport events. Competitive sport anxiety is a distrustful response that takes place when a player undermines his or her capability in dealing with demanding circumstances. Competitive sport anxiety affects player's ability to perform effectively in any sport competition. The purpose of the current research is to evaluate the competitive sport anxiety difference between Fijian and I-Taukei young soccer players. Participants consisted of sixty young soccer players ranging from ages $14-19$ years who participated in district youth soccer competition. A t-test was applied to measure the significance level between district level young $\backslash$ soccer players. The result of the study revealed that there is a significant difference between Fijian and the i-Taukei players. The Fijian players had higher mean anxiety scores than the I-Taukei players. Findings may assist coaches' understanding of the degree to which competitive sports anxiety exists in sports.
\end{abstract}

Keywords: Soccer, Young Players, Sports Anxiety, Level of competition.

\section{Introduction}

Success and failure in competitive games and sports depend on series of emotions. Players may feel worried, tensed, stressed and fear prior to or during a competition. Uncertainty causes anxiety in players. The significance of the event, level of competition and crowd contribute to player's anxiety. [1] The anxiety experienced can also affect an individual's overall level of self-confidence. Competitive sport anxiety is commonly found in young athletes. Anxiety is a negative response that takes place when players undermine their capabilities to manage certain circumstances. [2] Defined anxiety as a negative emotional condition that is illustrated by uneasiness, fear, discomfort, worry, and hesitation and is connected with activation or stimulation of the body. Anxiety is triggered by stressful stimuli and manifests itself in an individual's lack of adaptability on physiological, behavioral, and cognitive levels. In this way, it also hinders athletic performance [3].

Competitive anxiety is the tendency to determine antagonistic situations and take action accordingly with feelings of stress, pressure and nervousness [4]. The competitive anxiety instantly accelerates just before the competition and suddenly decelerates after the competition [5]. Generally competitive anxiety is a result of an individual's sentiment of stress, tension and failure. It is associated with sharp excitement of the automatic nervous system [6]. This explicit phenomenon, occurs during the twenty four hours before a competition, and is known as pre-competitive anxiety. Numerous studies have revealed that amateur players suffer more anxiety then professional players. Indeed, as the players' playing period increases, his anxiety level decreases. Professional players have paranormal ability to play with low level anxiety.

Many Studies have revealed numerous prospective causes of competitive anxiety. [7] Assessed young male and female sports competitors, to evaluate a list of feasible causes of minor stress and anxiety. Results showed that severe game pressure, over-competitiveness, and negative reaction increased stress for both male and female competitors. There is a great deal of scholarly inquiry into identifying techniques that can be used for managing performance anxiety in athletes such as relaxation, cognitive restructuring and positive self-talk method [8].

\section{II.I Sample}

\section{Methodology}

For the present study, sixty young soccer players were selected from participants in the district level soccer competition. The demographic information is as follows:

Table- 1

\begin{tabular}{|c|c|c|c|}
\hline \multicolumn{4}{|c|}{ Demographic Information of Young Soccer Players } \\
\hline \multicolumn{2}{|c|}{ Items } & Number of Participants & Percentage (\%) \\
\hline $\begin{array}{l}\text { Level of } \\
\text { Competition }\end{array}$ & District & ( & 100 \\
\hline Gender & Male & 60 & 100 \\
\hline$\underline{\text { Race }}$ & Fijian & 20 & 33 \\
\hline & I-Taukei & 40 & 66 \\
\hline
\end{tabular}


All the players were males.The subjects were divided into two groups according to their ethnicity. The group comprised of Fijian and I-Taukei players whose age ranged from 14 to 19 years.

\section{II.II Procedure}

The Sport Competition Anxiety Test (SCAT: Martens, 1977) was used in this study, which consists of 15 items that measure competitive sport anxiety. The questionnaires were distributed to the subjects. Instructions were provided before subjects filled in the questionnaires. The statistical analysis t-test was applied to determine the difference of competitive sport anxiety between Fijians and I-Taukei soccer players.

\section{Result}

Table-2

Descriptive Statistics of Competitive Sports Anxiety of Fijian and I-Taukei Young Soccer Players

\begin{tabular}{|l|c|c|c|c|c|}
\hline \multicolumn{1}{|c|}{ Variables } & $\mathbf{N}$ & Means & Std. Deviation & t-value & Level of Sig. \\
\hline Fijians & 20 & 22.85 & 2.96 & 2.62 & \multirow{2}{*}{$\mathrm{P}<0.01$} \\
\hline I Taukei & 40 & 20.75 & 2.85 & \\
\hline
\end{tabular}

*Significant Level is 0.01

In order to measure level of competitive state anxiety between Fijians and I-Taukei young soccer players, means and standard deviations were separately calculated. The findings indicated that there was a significant difference between Fijians and I-Taukei young soccer players. The mean score of the Fijian young soccer players was higher than the I-Taukei players.

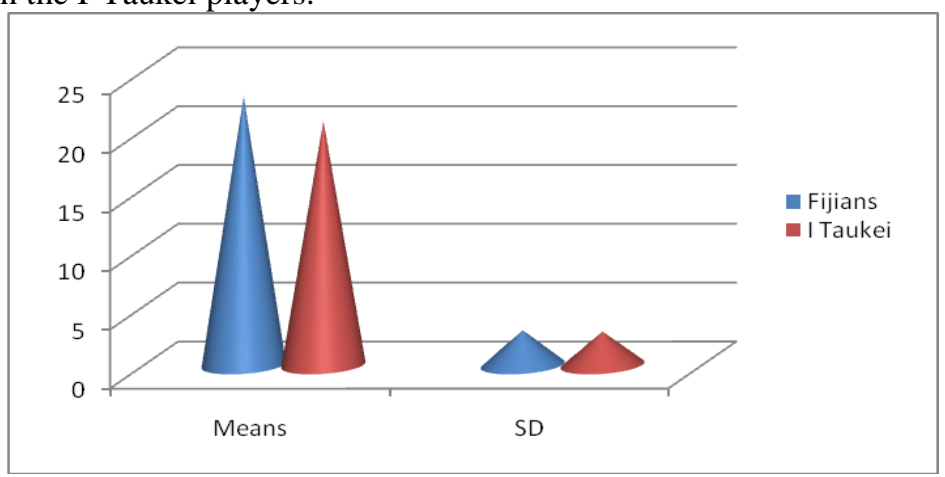

The graph shows responses of the Fijians (20) and I-Taukei (40) soccer players. It can be concluded that Fijian players have higher anxiety level than their counterparts.

\section{Conclusion}

The result of this study revealed that there are differences in competitive sport anxiety between the Fijian and I-Taukei young soccer players. The data analysis reveals significant difference between Fijian and ITaukei young soccer players. There are a number of inconsistencies between these findings and those of previous studies. This could be the consequence of using different means, or possibly having used a distinct training programme and not competition. It may also be related to the situation that arouses feelings of anxiety.

\section{References}

[1]. A. Peden, Cognitive techniques to manage performance anxiety in tennis.Coaching \& Sport Science Review, 43, 2007, 12-13.

[2]. R. Weinberg, \& D. Gould, Fundamentos de Psicología del deporte y el ejercicioFísico[Foundations of sport and exercise psychology]. (Barcelona: Ariel. 1996).

[3]. S.Tamorri, Neurociencias y deporte: Psicologíadeportiva, procesosmentalesdelatleta[Neuroscience and sport: Sport psychology, an athlete's mental processes]. (Barcelona: Paidotribo 2004).

[4]. R. Martens, D. Burton, R.,Vealey, L., Bump,\& D. Smith, The development of the Competitive State Anxiety Inventory-2 (CSAI2). 1990 .

[5]. D. Gould, L. Petlichkoff, \& R. S. Weinberg, Antecedents of temporal, changes in, and relationships between CSAI-2 subcomponents. Journal of Sport Psychology ,6, 1984, 289-304.

[6]. D. Hackfort, \& P. Schwenkmezger, Measuring Anxiety in Sports: Perspectives and Problems. Anxiety in Sports: An International Perspective (Washington, DC: Hemisphere.) 1989, 55-74.

[7]. M. Anshel, \& J. Delany, Sources of acute stress, cognitive appraisals, and coping strategies of male and female child athletes. Journal of Sport Behavior, 24(4), 2001, 329-33

[8]. M. Humara, The Relationship between anxiety and performance: A cognitive - behavioral perspective. The Online Journal of Sport Psychology 1(2),1999, 126-130. 